Article

\title{
Modeling Green Energy Development Based on Sustainable Economic Growth in China
}

\author{
Zhijuan Zhang ${ }^{1, *}$ and Marcin Lis ${ }^{2}$ (D) \\ 1 School of Business, Henan University, Kaifeng 475004, China \\ 2 Department of Management, Faculty of Applied Sciences, WSB University, 41-300 Dabrowa Górnicza, \\ Poland; mlis@wsb.edu.pl \\ * Correspondence: zhangzhijuan@henu.edu.cn
}

Received: 19 December 2019; Accepted: 7 February 2020; Published: 13 February 2020

\begin{abstract}
Industrial development of the economic system of any state is directly related to the use of energy potential. China's industrial breakthrough is no exception. Today, China is one of the largest importers-consumers of oil, whose economy is extremely dependent on the energy market. The growing production and population, as well as climatic changes that directly determine the well-being of society, have become the causal basis for the development of alternative ways of generating energy. The aim of the study is to model the implementation of the sustainable development strategy in China through the production and use of biofuels. The simulation is made taking into account the following. The production capacities of Chinese licensed producers of fuel ethanol are calculated. The efficiency of bioethanol production from various types of biological raw materials is evaluated. An economic and mathematical model of bioethanol production is built. The article forecasts the profitability of bioethanol sales from various types of biological raw materials (sugar sorghum, corn) in Chinese and European markets. The study comprehensively reveals the features of the use of biofuels in an industrial country, taking into account geopolitical factors, social and market contexts, as well as technical analysis of the raw materials and production potential of Chinese companies. The article also interprets the economic processes associated with the introduction of biofuels in the ecological and economic systems of China. The article demonstrates other concepts regarding the consequences of the energy sector's transition to the principles of energy production from biomass. The article shows the contradictory nature of the impact of biofuel production on the food market and the agricultural sector. The article analyzes possible social, resource and macroeconomic risks, and also indicates possible vectors for further research that might be aimed at diversifying the associated negative processes.
\end{abstract}

Keywords: bioethanol; green energy; sustainable development; alternative energy; biofuel

\section{Introduction}

The extensiveness of countries' industrialization methods in the last century both became the basis for industrial progress and left a negative imprint on the environmental status in the world. The "Chinese economic miracle", which laid the foundation for a qualitatively new stage in the social and economic development of China, as a national model ceases to be competitive in the conditions of limited and non-renewable traditional energy resources. An energy-intensive economy needs conceptually new sources of energy, which, in addition to improving the environmental working and living conditions of the population, will also provide macroeconomic, raw material security to the state [1-3]. Moving away from traditional energy sources is a difficult task for an industrial state. However, the need for sustainable development, which de facto determines the forecast of the country's socio-economic future, forces China to consider options for the fastest transition to the use of "green 
energy". Thus, there is a need for comprehensive predictive modeling of the production processes and use of biofuels in China in order to identify possible macroeconomic risks in advance-which is the purpose of the study.

In recent years, the world has entered the era of bioeconomics-a biotechnology-based economy that uses renewable raw materials to produce energy and materials [4]. Given that natural mineral fuels are almost exhausted, energy production from renewable (alternative) sources is becoming relevant and undoubtedly it will only increase in the future. The population of our planet over the past century has increased by about 4.25 times, and annual oil production-by almost 20-21 times. Hydrocarbon production is increasing in proportion to the growth of the world's population. At such rates of use over the next 30-40 years, almost all fossil fuel reserves will probably be exhausted $[5,6]$.

The solution to this problem is the search for new energy sources based on renewable energy crops. Therefore, the basis of modern scientific areas in developed countries is the research and development of alternative forms of energy, including renewable. The biomass of plants is of particular interest, as long as plants have many advantages over fossil carbohydrates. In order to preserve natural resources and improve the environment, scientists have proposed to create a closed cycle of energy use and recycling. This becomes possible with the use of renewable types of liquid fuels based on bioethanol and biodiesel [6,7]. Meanwhile, the active introduction of alternative types of energy, including bioenergy, into almost all spheres of life, is gaining increasing economic and social significance and is currently one of the main strategic priorities for the innovative development of the global economy.

The results of expert evaluations [8,9] indicate that by 2050 energy consumption worldwide will double, which, in turn, will lead to a doubling of the $\mathrm{CO}_{2}$ content in the Earth's atmosphere and an increase in the greenhouse effect. Industrial cities of China face rather serious environmental conditions. There is the task of satisfying the needs of the population, industry, and agriculture for electric and thermal energy, especially in regions that are located far from centralized energy networks. The latter leads to the need to develop energy, which is based on alternative energy sources, the most important of which is organic biomass [10,11]. In 2006, the Chinese government increased its focus on energy efficiency and pollution control, positioning it along with other key elements of China's domestic policy. In addition, in 2016-2018 more stringent emission standards were introduced in China for vehicles and the composition of retail gasoline fuel [12].

In general, over the past two decades, thanks to a series of plans consisting of four five-year plans (FYPs), China has evolved from a zero-biofuel producer to the fourth-largest producer in the world compared to a decade ago. As a result, China's fuel ethanol policy has shifted to a policy of expanding national capacities and productivity for the production of fuel ethanol and reorienting some of its alcohol enterprises to bioethanol production $[12,13]$.

As a result, the research questions addressed in this study are as follows:

- Analyzing the state and development prospects of the green energy industry in China.

- Exploring issues related to the technology of fuel production based on crops as a raw material resource.

- Studying the world prospects for green energy development and the transition of transport to this type of fuel in the conditions of limited oil and gas reserves and harmful effects on the environment.

- Designing a model for the development of innovative bioeconomics on alternative (biological) fuels.

- Developing and testing an economic and mathematical model of bioethanol production.

- Evaluating the effectiveness of bioethanol, which is produced from various types of biological raw materials (sugar sorghum, corn) in the Chinese, European, American markets and markets of the Asia-Pacific region. 


\section{Literature Review}

Over the entire history of the development of human society, energy consumption per person has increased more than 100 times. For every 10-15 years, the world level of energy consumption almost doubles. The reserves of traditional sources of energy: oil, coal, gas-are depleted, and the burning of fossil fuels pollutes the environment more and more, which causes the need to obtain energy using environmentally friendly technologies [1,14].

There is a pronounced need of finding alternative fuels due to the dynamic rise in the price of fuel resources in the world, the growing needs of most countries of the world, including China in providing energy sources of its own production. Growing crops for processing into biofuels (ethanol, biodiesel) should be considered as an important innovative direction of agricultural production in the context of sustainable development. Since the latter is able to solve a number of economic, environmental and social problems. Biofuels are important, especially for energy, resource conservation and environmental improvements [3,15].

The bioenergy industry faces a number of problems of an economic, environmental and technical nature that require immediate or gradual resolution. Bioeconomics as science is aimed at preventing environmental pollution, reducing emissions of gases that cause the greenhouse effect, and other toxic substances. In this regard, there is active use of renewable energy sources, incl. crops, in the USA, Japan, Brazil, China, India, Canada, EU countries. Thus, from these raw materials, it is possible to produce such energy products as bioethanol, biodiesel and biogas. In general, the cultivation of crops for processing into biofuels (ethanol and biodiesel) should be considered as one of the most important innovative areas of agricultural production in the context of sustainable development. Since the latter can solve a number of economic, environmental and social problems $[9,16,17]$.

Technological bioenergy should be considered as one of the areas of environmental biotechnology associated with the efficient use of the energy of photosynthesis [17]. At the present stage of bioenergy development, the main energy products in this area are bioethanol, biodiesel and biogas. Bioethanol and biodiesel are intended for use as a motor fuel, ethanol is also an important raw material for the chemical industry. Therefore, the production of bioethanol plays an important role in the transition from a traditional economy based on the use of non-renewable resources to an environmentally friendly economy. Bioethanol is important for the industry as well [18].

Hence, the two main areas of technological bioenergy are:

- Conversion of accumulated biomass into cheap and high-calorie fuel. Biomass is a source of almost costless renewable energy, and is an alternative to mineral reserves, decreasing every year. - Modification of the process of photosynthesis itself, as a result of which the energy of light without the assimilation of $\mathrm{CO}_{2}$, without the growth of biomass, will be immediately used for the formation of hydrogen or another type of fuel $[18,19]$.

Agricultural waste that can be used as solid biofuel includes winter and spring crop straws, corn trunks and ears, husks and sunflower trunks. Straw is also used for such purposes as feed and underlay for animals. It is estimated that $30 \%$ of all straw can be used as fuel. In addition, part of the corn stalks is used for other purposes. Thus, it is estimated that $50 \%$ of the rest of the corn stalks can be used for energy production $[20,21]$.

\section{Methods}

\section{Research Design}

Starting to carry out the analytical part of the study, it is important to justify the strategically important development of the alternative energy industry in China and around the world, especially for industrially active countries and regions.

In general, the prospects for the increasing demand for fuel for the activities of industrial enterprises and transport in China in the near future depend on: 
- Macroeconomic factors.

- $\quad$ The degree to which the requirements for NEVs (new energy vehicles) are met.

- $\quad$ The degree to which China's national goal is met in the consumption of fuel ethanol E 10 [22].

In terms of public health and the environment, biofuels are part of China's long-term strategy to conserve resources, improve air quality and reduce its dependence on imported fossil fuels. Fuel ethanol is an efficient fuel oxygenate at a competitive price that can help China meet its domestic and international obligations to reduce air emissions, toxic chemicals and greenhouse gas emissions. It is possible to achieve this result if diesel products based on fossil fuels are mixed with biodiesel. However, in China, for the time being, there is still no national policy on the use of biodiesel. Thus, the country's energy policy still needs to be improved [12].

The key problems in the biofuel industry development are the raw material base and technology. First-generation biofuels are produced using simple, industry-standard technologies. For the production of biofuels of the second and subsequent generations, more advanced and expensive technological methods are required [23].

\section{Data Analysis}

In the long term, the ever-growing demand for biofuels from land, air and sea transport can greatly change the current situation in the global energy market. According to forecasts of the International Energy Agency (IEA), oil shortages in 2025 will be estimated at $14 \%$. Hence, the only option for a huge global vehicle fleet is a gradual decline in gasoline and diesel fuel usage. According to the IEA, the total production of biofuels (incl. bioethanol and biodiesel) in 2012 amounted to 110 billion liters. That is, even if this level of production is doubled by 2021, the global fuel demand will be covered only by $7 \%$. The growth rate of biofuel production is far behind the growth rate of demand for it. This is due to the need for cheap raw materials and insufficient funding. The massive commercial use of biofuels will be determined by the achievement of price equilibrium with traditional fuels derived from oil [23-25].

Plans to begin production of biofuels at the state level have already been adopted in more than 38 countries. The world centers for biofuel production today are the USA, Brazil, the European Union and China. These are the largest markets in the world, concentrating $85 \%$ of global biofuel production. The largest share is in the United States of America- $48 \%$ of biofuels in the world. The most common type of biofuel is bioethanol, its share is $82 \%$ of the world's total fuel produced from biological raw materials. Its leading manufacturers are the United States and Brazil. Biodiesel occupies second place, with $49 \%$ of biodiesel production being concentrated in the European Union. In China, biofuel production capacity, according to domestic experts, reaches 3.38 million tonnes per year. Around $42 \%$ of this volume is produced from corn, over $50 \%$ from cassava, the rest is from wheat, sorghum or rice, depending on the specific area of China $[10,20,26]$.

At present, the construction of new biofuel production plants with a total capacity of 6.6 million tonnes per year is already underway in China [13]. By 2020, according to the governmental decision, the whole country will switch to using motor fuel with the addition of bioethanol, which will require 15 million tonnes of biofuel annually $[25,27]$. Nowadays, in the field of production and sale of biofuels, China, unfortunately, is inferior to powerful Western competitors. This area of business is rapidly developing, as evidenced by the global growth trend in biofuel production, which is sold on world markets (see Figures 1 and 2). 


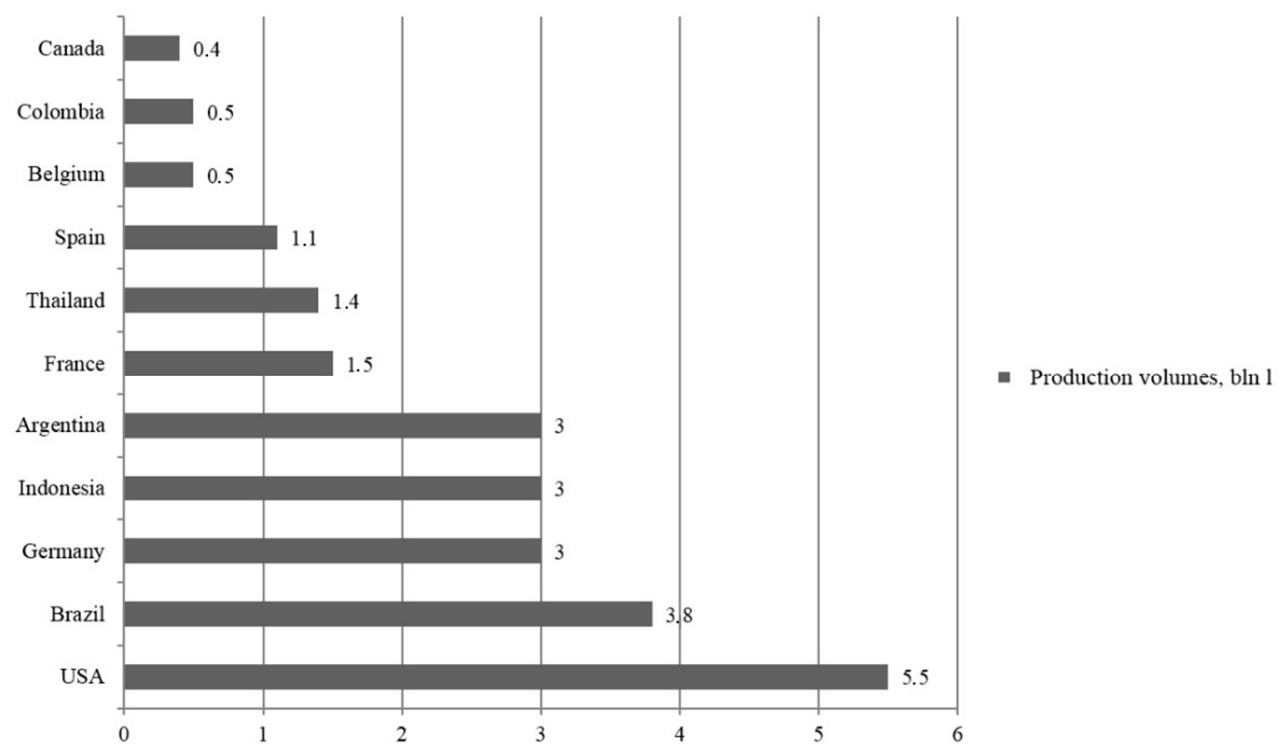

Figure 1. Production volumes of biofuels (bioethanol, biodiesel and biogas) by leading countries, 2018, bln. liters Source: Authors' elaboration based on [28].

However, at the same time, China is the largest energy consumer in the world, surpassing the United States as the largest consumer of crude oil in 2017. In 2000, in China, there were less than 20 million passenger vehicles. From 2005 to 2015, China's passenger vehicle fleet increased tenfold. In 2018, China surpassed the United States as the largest automobile market in the world, totaling more than 322 million vehicles $[20,21]$.

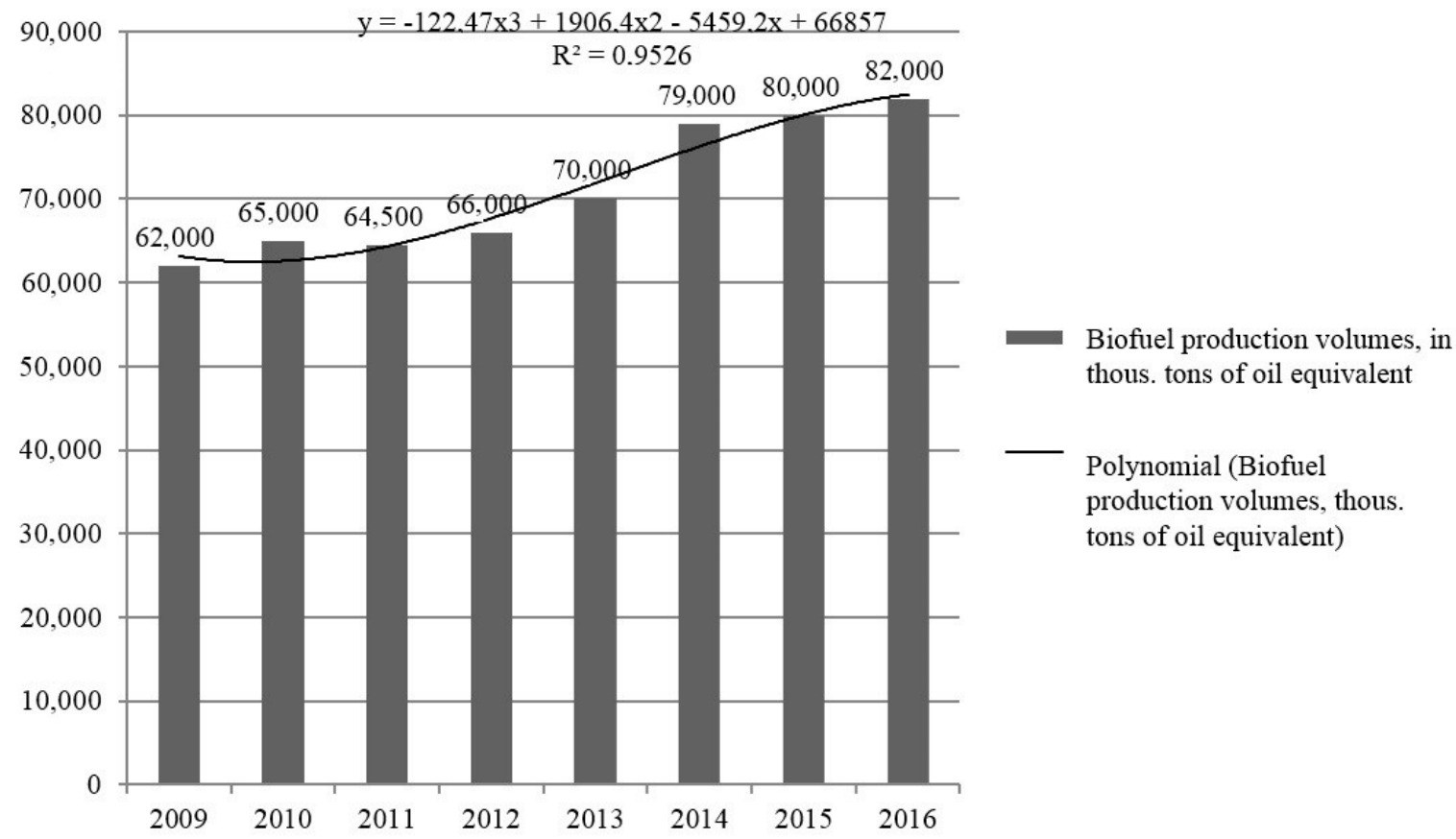

Figure 2. Global volumes of biofuel production (bioethanol, biodiesel and biogas), in 2018, in thousands of tonnes of oil equivalent. Source: Authors' elaboration based on [28].

According to estimates by the Chinese government, the expected production of fuel ethanol will be about 4 million tonnes (1.339 billion gallons) per year during the 13th five-year plan. In 2017, ethanol production amounted to 2.6 million tonnes ( 0.871 billion gallons) per year, showing an increase of 
0.5 million tonnes ( 0.167 billion gallons) per year if compared to 2.1 million tonnes ( 0.703 billion gallons) in 2016. In 2018, ethanol production increased to 3 million tonnes (1.005 billion gallons) per year. By the end of 2019, total ethanol production is projected at 3 million tonnes (1.005 billion gallons) [11,29]. In a consolidated form, the data are presented in Figure 3.

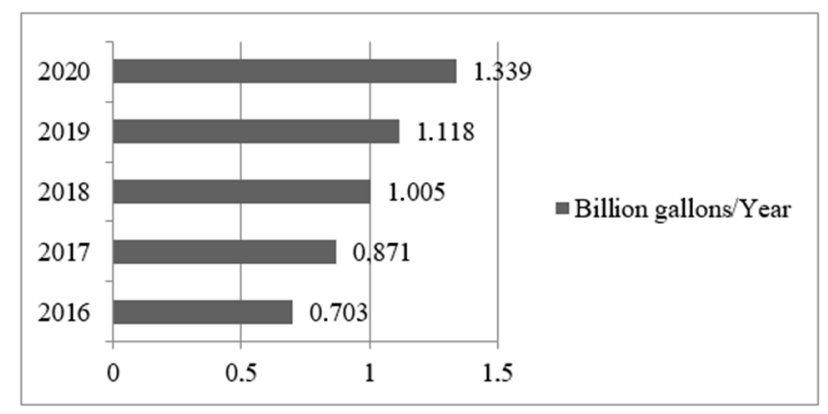

Figure 3. Chinese fuel ethanol production for the $13^{\text {th }}$ Five-Year plan. Source: Authors' elaboration based on $[12,13]$.

According to the government's plans, for the 13th five-year plan, the Chinese government is planning to invest another 18 billion CNY (about $\$ 2.8$ billion) into the industry. The latter indicates several possible ways for the industry to develop. First, China can plant more cassava and sorghum in some unproductive lands and waste areas, such as salt marshes and alkali soils. Secondly, China will actively invest in the development of ethanol production from cellulose fibers, for which inedible parts of plants are used. Thirdly, China intends to accelerate the expansion of land for growing corn for ethanol production, which will be the main way to increase the production of fuel ethanol. However, it is worth noting that this plan has some implications for the ethanol and corn markets and related fuel products in the United States, in terms of increased competition from China. For example, in Iowa, the price of DDGS was \$ 122 per ton in January 2018 and fell to \$ 93 per ton in May 2018 [11,12].

Based on the implementation of the "13th Five-Year Plan", China plans not only to accelerate the production of fuel ethanol, but also to expand its use. The Chinese government indicates that the expected $10 \%$ blend of ethanol with gasoline (E10) will be applied nationwide, according to a report from the China Petroleum News Center. The report also states that so far, fuel ethanol is planned to be used in 11 provinces. Six of them, that is, Liaoning, Jilin, Heilongiiang, Henan, Anhui and Guangxi, must supply E10 gasoline for all gas stations. While the other five provinces, that is, Jiangsu, Hubei, Hebei, Shandong and Guangdong, might supply both regular gasoline and E10 gasoline. Until 2020, the Chinese government has announced the popularization of E10 gasoline for the whole country [22].

In order to achieve the above-mentioned goals, the demand for fuel ethanol should reach 13 million tonnes ( 4.35 billion gallons) per year. While the current production of fuel ethanol is so far about three million tonnes ( 1.005 billion gallons) per year. Thus, the difference between demand and supply may lead to certain changes in the ethanol fuel industry, especially corn-based [11,12]. There was an analysis of projects, strategies and regulatory documents in the development of the national alcohol industry in China in recent years [30]. Thus, at this time, the priority areas for the development of the state's alcohol industry are the production of high-tech biofuels by Chinese industrial enterprises. These biofuels will be in high demand in domestic and international markets.

The researches $[3,7,9,13,17,31]$ in the field of the alcohol industry development have determined that the production of alternative fuels (bioethanol, biodiesel, biogas) is undoubtedly a priority in the global production of motor fuels. According to expert estimates [4,32,33], at the end of 2018, there were more than six hundred large industrial enterprises and their associations in the world for the production of alternative types of fuel (bioethanol, biodiesel, biogas). The total capacity of these enterprises is more than 900 million tonnes of oil equivalent. As a result of bioethanol and gasoline blend, the oil saving in 2015-2016 was more than 60 million tonnes of oil equivalent, which is equal to 
its annual consumption in the Netherlands and Poland in total. The world leaders in alternative fuel production are the USA, EU, Brazil, China, Canada, etc. [34,35].

Figure 4 shows the dynamics of alternative fuel production (USA, Brazil, EU) for recent years. Thus, for example, according to the IEA's forecasts, the expected volume of bioethanol production in the world in 2020 will be from 190.5 billion liters to 290 billion liters per year. World trade will be about $11.5 \%$ of the total global production [4]. China should increase the production of biofuel and strengthen its position in the world market as an exporter. In order to do so, China needs to increase the cultivation of alternative crops as new potential raw materials.

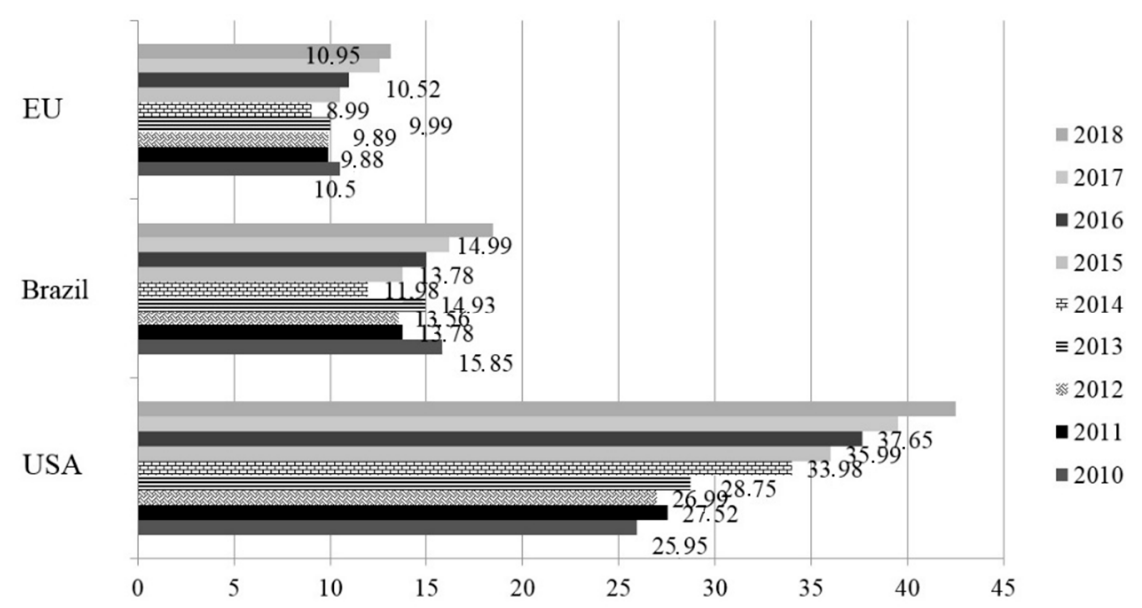

Figure 4. The dynamics of alternative fuel production in the USA, Brazil and the EU, mln tonnes of oil equivalent Source: compiled by authors based on a study of the following statistical and analytical sources of information $[12,13,21,33]$.

It should be noted that bioethanol, which has the lowest cost, is produced by Brazil and the United States under the conditions of subsidies for its production. At the same time, at German alcohol enterprises, bioethanol production is the most expensive. With the direct method of processing the raw materials of sorghum and corn for bioethanol, the unit cost price in China is lower than in Europe and some other Asian countries. The latter may provide an opportunity for China to take a leading place among producers in the Asia-Pacific region and also oust western producers $[2,34,36]$.

The efficiency of bioethanol production on alternative (biological) types of raw materials is analyzed down below.

Information data from press releases of IEA's projects indicate that alternative (biological) sources are indeed gaining increasing strategic importance. Such sources (based on which alcohol products are made) are highly ecological and low cost. These alcohol products might be in demand in European markets if Chinese producers enter these markets [25]. Thus, it was revealed that bioethanol in modern conditions is produced by the method of fermentation of sugars, glucose, sucrose in an oxygen-free environment supported by yeast [19].

As can be seen, in China and around the world there is a constant increase in the production of bioethanol. Thus, starting from 2009-2010, according to the international statistical resource The Statistics Portal, bioethanol production increased by about 6.5 times, while biofuels as a whole-by about 9.5 times. For example, in 2017, total biofuel production volumes amounted to more than 35 billion liters, of which 4.5 billion liters accounted for food-grade ethanol, 9.5 billion liters for chemical products, 21 billion liters for fuel energy products [12]. The use of bioethanol in gasoline can significantly reduce the level of harmfulness of toxic emissions into the earth's atmosphere. In the USA, according to norms, there should be about $9-10 \%$ of bioethanol in gasoline, in Canada $-7 \%-9 \%$, in the EU countries- $5 \%-6.5 \%[20,21,37]$. 
In general, the results of the study indicate that the use of crops in the production of alternative (biological) types of fuel is a strong potential for the energy supply of the national economy and the state as a whole, as well as a strategic reserve for the future (see Table 1).

Table 1. Evaluation results of the strategic importance of ethanol production from traditional and alternative raw materials.

\begin{tabular}{|c|c|c|c|c|}
\hline No. & Type of Culture & $\begin{array}{l}\text { Average Crop Yield, } \\
\text { Quintal Per kg }\end{array}$ & $\begin{array}{l}\text { The Output of Ethanol } \\
\text { from } 1 \text { Quintal of Raw } \\
\text { Materials, in Liters }\end{array}$ & $\begin{array}{l}\text { The Total Amount of } \\
\text { Ethanol, in Tonnes }\end{array}$ \\
\hline \multicolumn{5}{|c|}{ Traditional raw materials } \\
\hline 1. & Corn grain & 49.5 & 39.5 & 1950 \\
\hline 2. & $\begin{array}{l}\text { Cereal crops } \\
\text { (barley, wheat) }\end{array}$ & $30.5-40.5$ & 34.6 & 1190 \\
\hline \multicolumn{5}{|c|}{ Alternative raw materials } \\
\hline 1. & Sorghum Syrup & $690-790$ & 9.1 & $3450-3900$ \\
\hline 2. & $\begin{array}{c}\text { Jerusalem } \\
\text { artichoke syrup }\end{array}$ & $305-345$ & 9.8 & $2450-2900$ \\
\hline 3. & Chicory Syrup & $210-255$ & 9.8 & $2100-2450$ \\
\hline
\end{tabular}

Source: compiled by authors based on scientific and analytical reports of the Joint EU Research Center (as part of the OECD) and Chinese scientists.

The following should be noted about the prospects for bioethanol production in China. The national agro-industrial complex has a powerful raw material base, which can be focused on growing crops (in particular, sugar sorghum and corn). The latter are raw materials for the production of alternative (biological) fuels. However, the main obstacle is the insufficient workload of alcohol enterprises in China $[4,30]$.

\section{Results}

The results of the study have already substantiated the strategic importance of producing a highly environmentally friendly type of alcohol-bioethanol. The latter is a source of alternative energy. Alternative energy is a fundamentally new industry in modern bioenergy and requires the formation of a scientific basis and modern methodological and technological approaches to solve numerous problems in this area. In this regard, the aggregate segment of national bioenergy can turn into a key element in the formation in China of a whole new direction of the "alternative" economy-innovative bioeconomics [4].

Given the importance of the scientific component in the development of innovative technologies for the production of biofuels, a model for the development of innovative bioeconomics on alternative (biological) fuels is proposed in the work (Figure 5). 


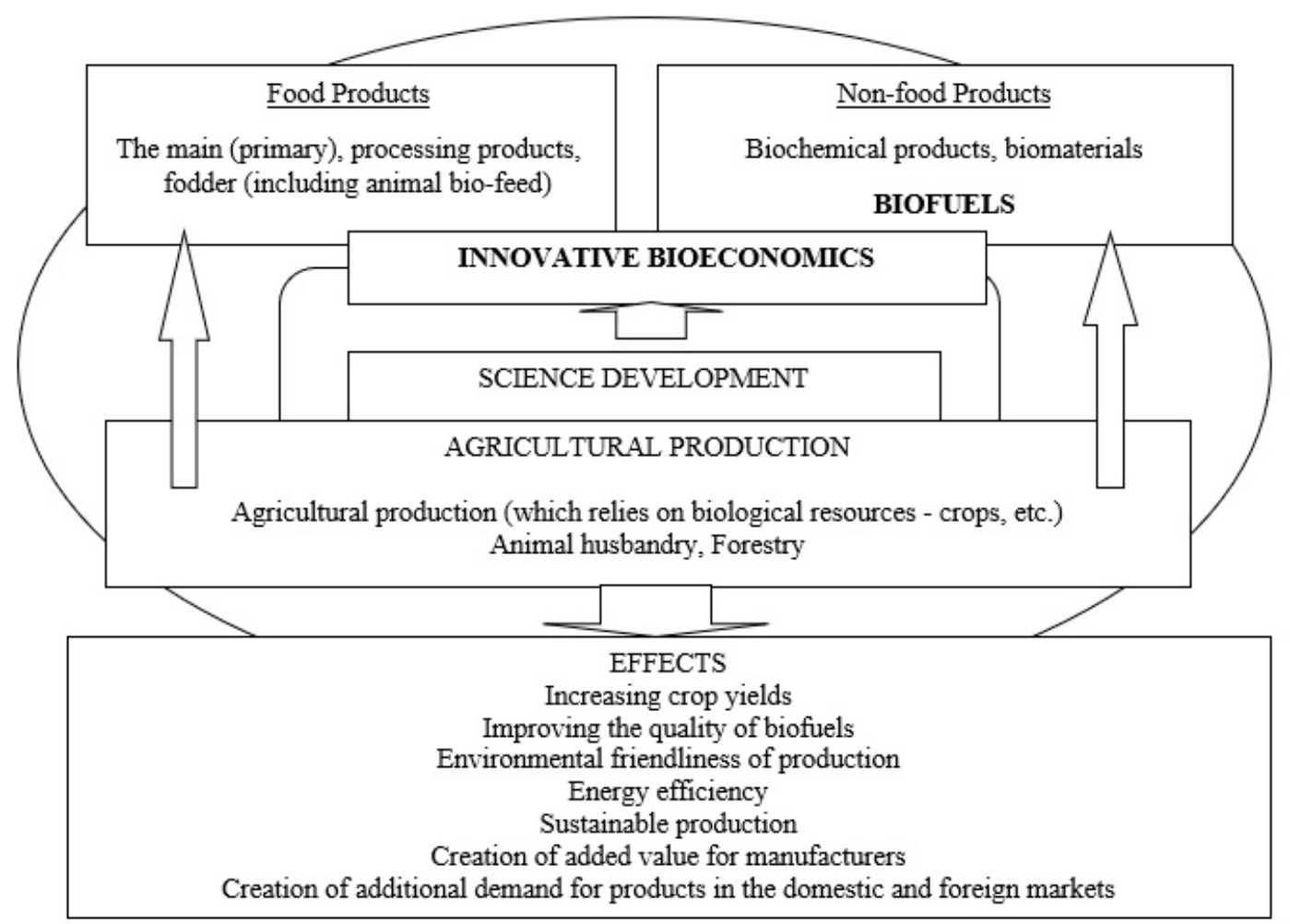

Figure 5. Model for the development of innovative bioeconomics on alternative (biological) fuels. Source: developed by authors.

The possibility of developing China's alcohol industry on the principles of sustainable economic growth is considered below. The latter is based on additional loading of existing capacities through the production of bioethanol on natural raw materials—sugar sorghum and corn.

Figure 6 shows the ethanol production when using various types of biological raw materials-Jerusalem artichoke root, sugar sorghum, wheat, and corn.

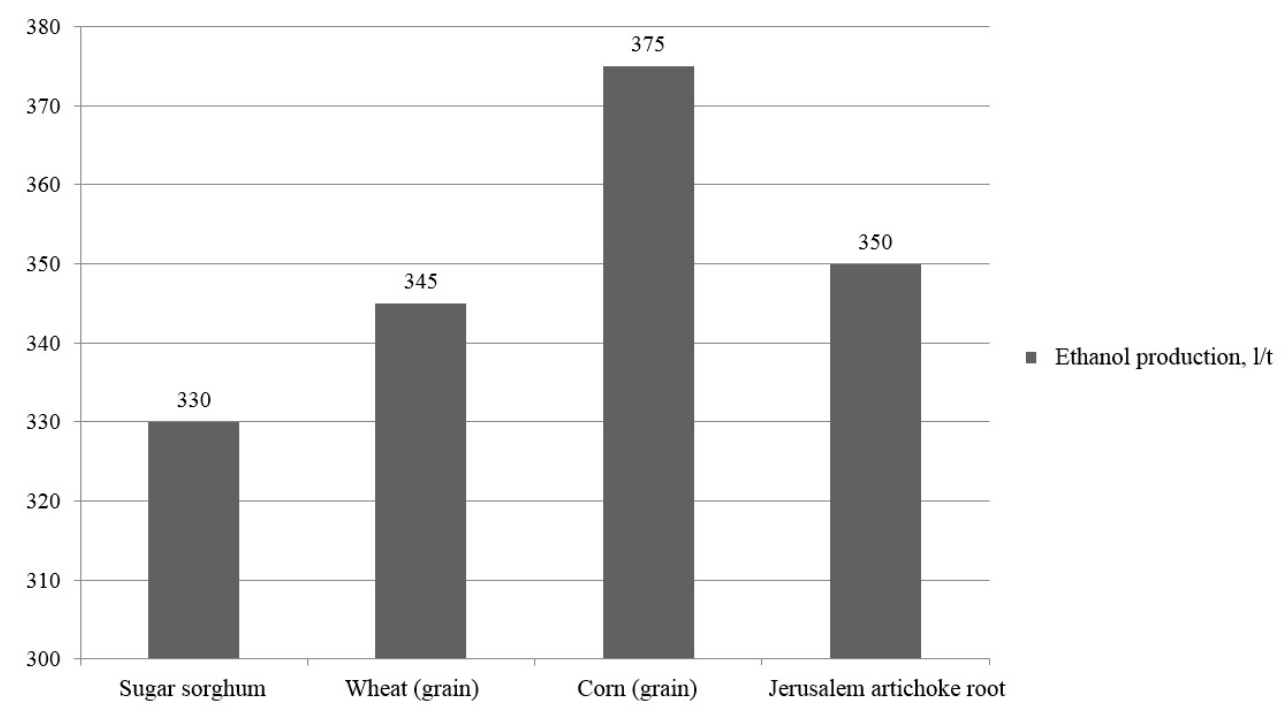

Figure 6. Ethanol production when using various types of biological raw materials. Source: authors' elaboration based on $[18,19]$. 
Tables 2-4 show the results of evaluating the efficiency of bioethanol production from various types of biological raw materials (sugar sorghum, sugar beets, corn, wheat). Bioethanol sales in the domestic and European markets are also shown as of the end of 2017. The latter is according to the level of profitability of the domestic market. The average weighted value was calculated for the last few years, according to the financial statements of Chinese enterprises of the alcohol industry-12-15\% [38]. National alcohol enterprises are currently oriented to the needs of bioethanol production. The power capacity of these enterprises is given in Table 2.

Table 2. Production Capacity of China's Fuel Ethanol Licensed Producers (2018 Estimates).

\begin{tabular}{cccc}
\hline Producers & Million Liters & Tonnes & Notes \\
\hline Jinlin Fuel Alcohol & 887 & 700,000 & \\
Henan Tianguan & 887 & 700,000 & Production reportedly \\
suspended in 2018 \\
COFCO Biochemical (Anhui) & 798 & 630,000 & \\
COFCO Bioenergy (Zhaodong) & 507 & 400,000 & \\
SDIC (Zhanjiang) & 190 & 150,000 & \\
Shandong Longlive & 63 & 50,000 & Production reportedly \\
Suspended in 2018 \\
COFCO Bioenergy (Guangxi) & 253 & 200,000 & \\
ZTE Zonergy (Inner Mongolia) & 38 & 30,000 & Production reportedly \\
& & & suspended in 2018 \\
SDIC (Tieling) & 380 & 300,000 & Production on line in \\
September 2018 \\
Liaoyuan Jufeng Biochemical & 380 & 300,000 & \\
Jilin Boda Biochemistry & 507 & 400,000 & \\
Jiangsu Lianhai Biotechnology & 152 & 120,000 & \\
TOTAL & 5042 & $3,980,000$ & \\
\hline
\end{tabular}

Source: Authors' elaboration based on [4,13].

Nowadays, there is a high global market demand for natural crops, in particular, corn and sugar crops (sugar sorghum stalks). The cultivation of the latter is of the highest priority due to China's geographical location, soil structure, climatic conditions and resource opportunities. Bioethanol can be produced without waiting for the construction of new biofuel plants. It is proposed to reload alcohol companies in China for producing export-oriented bioethanol.

Table 3. The results of evaluating the efficiency of bioethanol production from various types of biological raw materials (sugar sorghum, corn).

\begin{tabular}{cccccc}
\hline No. & $\begin{array}{c}\text { Type of } \\
\text { Biological Raw } \\
\text { Material }\end{array}$ & $\begin{array}{c}\text { Productivity, } \\
\text { t/ha }\end{array}$ & $\begin{array}{c}\text { Bioethanol } \\
\text { Production, } \\
\text { t/ha }\end{array}$ & $\begin{array}{c}\text { The Production of } \\
\text { Purified Bioethanol } \\
\text { from 1 t of Output, } \mathbf{t}\end{array}$ & $\begin{array}{c}\text { Cost of 1 Tonne of } \\
\text { Bioethanol, USD }\end{array}$ \\
\hline 1. & Sugar sorghum & 7.1 & 2.02 & 0.28 & 410.1 \\
2. & Corn & 5.89 & 1.377 & 0.22 & 362.23 \\
\hline
\end{tabular}

Source: Authors' elaboration based on [35,38,39]. 
Table 4. The sales effectiveness of bioethanol from various types of biological raw materials (sugar sorghum, corn) in the Chinese and European markets.

\begin{tabular}{|c|c|c|c|c|c|c|c|}
\hline \multirow[t]{2}{*}{ No. } & \multirow{2}{*}{$\begin{array}{c}\text { Type of } \\
\text { Biological } \\
\text { Raw } \\
\text { Material }\end{array}$} & \multirow{2}{*}{$\begin{array}{l}\text { Cost of } 1 \\
\text { Tonne of } \\
\text { Bioethanol, } \\
\text { USD }\end{array}$} & \multirow{2}{*}{$\begin{array}{c}\text { Bioethanol } \\
\text { Selling Price (Set } \\
\text { by Chinese } \\
\text { Manufacturers) } \\
\text { on Domestic } \\
\text { Market, USD/t }\end{array}$} & \multirow[t]{2}{*}{$\begin{array}{c}\text { Return on } \\
\text { Sales, \% }\end{array}$} & \multicolumn{2}{|c|}{$\begin{array}{l}\text { Bioethanol Selling } \\
\text { Price (Set by Chinese } \\
\text { Manufacturers) for } \\
\text { Export }\end{array}$} & \multirow[t]{2}{*}{$\begin{array}{c}\text { Return on } \\
\text { Export } \\
\text { Sales, \% }\end{array}$} \\
\hline & & & & & $€ / t$ & USD/t & \\
\hline 1. & $\begin{array}{l}\text { Sugar } \\
\text { sorghum }\end{array}$ & 410.1 & 442.33 & 12.2 & 392.1 & 475.04 & 20.5 \\
\hline 2. & Corn & 362.23 & 408.23 & 12.7 & 369.2 & 447.36 & 23.5 \\
\hline
\end{tabular}

Source: calculated by authors based on $[4,12,13,18,19,30,37,38,40]$.

According to the above tables, it can be seen that the production and sale of bioethanol for export is much more profitable than focusing on the domestic market.

The optimal loading of alcohol enterprises with bioethanol production is determined using the methods of economic and mathematical modeling. These are scientific research methods, which, on the one hand, describe all the main relationships that characterize the studied phenomenon (process, task). On the other hand, these methods reveal and develop the internal economic and mathematical logic of the studied phenomena. Thus, new connections and patterns can be qualitatively found. There is a clear statement of the problem. The problem's output and desired values are indicated. The algorithm is constructed, combined with the ability to quickly solve a number of different problems. Thus, the existing concepts are reassessed and, as a result, new connections, phenomena, and new theoretical generalizations are discovered. There is an economic and mathematical task to substantiate the choice of biological raw materials for bioethanol production.

Value designations:

i-types of plant raw materials offered for the production of bioethanol (sugar sorghum, sugar beets (molasses), corn, wheat)

n-types of bioethanol produced (based on raw materials: sugar sorghum, corn)

$P_{\text {sales }}$ - selling price of the obtained organic bioethanol, $€ / t$, (Table 5, data from $<$ The globalpetrolprices.com>, Figure 7)

$\mathrm{P}_{\text {purchase }}$ - purchase price of i-th type of raw material (sugar sorghum, corn) to ensure the production process, USD/tonne (Table 5, data from the reporting of alcohol enterprises in China).

The following components are proposed in the variable system:

$\mathrm{x}_{\mathrm{i}}$ - it is proposed to choose the amount of the $\mathrm{i}$-th type of organic bioethanol produced (sugar sorghum, sugar beets (molasses), corn, wheat), in tonnes, under the conditions:

- $\quad$ the possibility of reloading the existing alcohol enterprise with bioethanol production;

- bioethanol production settings at selected enterprises (equipment, labor with the necessary qualifications, etc.);

- $\quad$ support from the state tax and fiscal policy of the production and sale of Chinese bioethanol in the domestic and foreign markets (in particular, western markets and markets of the Asia-Pacific region).

$\mathrm{y}_{\mathrm{i}}$ - production load coefficient of alcohol enterprises, taking into account the additional load of bioethanol production.

It is proposed to use the following model components as a system of limitations of the economic and mathematical model:

$\mathrm{Q}_{\max }$ - maximum production capacity of the alcohol enterprise;

Press releases from the Ministry of Agriculture of the People's Republic of China and the reporting of a number of leading alcohol enterprises in China are analyzed (Table 2). The average capacity of 
enterprises is now about 14,220 thousand tonnes and a load of non-core alcohol enterprises for the production of other types of products is about $60-70 \%$. The study suggests reloading capacity with bioethanol production on corn and sorghum.

$\mathrm{P}_{\max }$ - the maximum allowable price for bioethanol. In accordance with the chosen direction of achieving close to a high level of competitiveness of bioethanol. Provided that the Chinese bioethanol price for European consumers should not exceed the average European market price.

For comparison, the authors of the current study have used price lists of Chinese and European biofuel distribution companies $[13,36,38,39]$. As of the end of 2018 , it was revealed that the maximum allowable price level at which bioethanol can be sold on European markets is $0.95 € / 1$, Figure 7 .

In accordance with the goal of increasing the reliability of the calculations, the following coefficient system is also proposed for use:

$\mathrm{k}_{\mathrm{cy}}$-coefficient of an objective function, yield fluctuations depending on climatic, geographic and weather conditions;

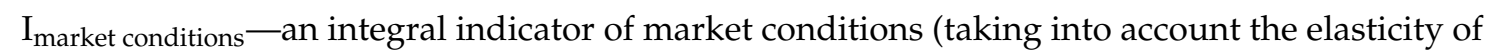
demand for bioethanol, the factor of seasonality and European bioethanol market conditions);

$\mathrm{I}_{\text {internal market conditions - coefficient of an objective function, taking into account the internal }}$ bioethanol market conditions;

$\mathrm{k}_{\text {risk }}(\mathrm{E}$ (ri))—coefficient of an objective function, taking into account the risks associated with problems and restrictions of Chinese bioethanol sales in European markets;

$\mathrm{k}_{\text {internal risk }}(\mathrm{E}$ (ri)) — coefficient of the objective function, taking into account risks associated with problems and limitations of bioethanol sales in the domestic market.

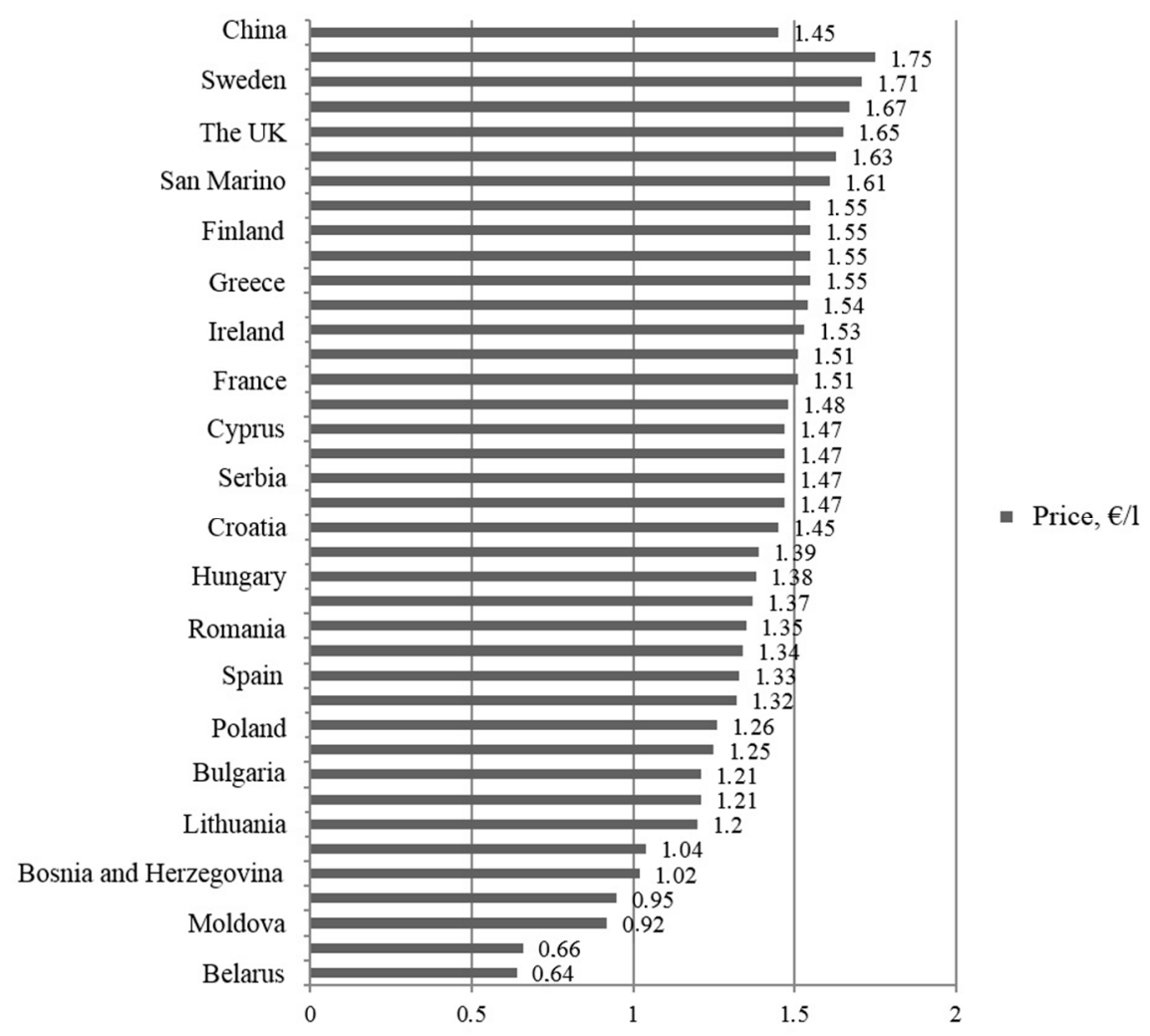

Figure 7. Average biofuel prices in the EU, CIS and China. Source: Authors' elaboration based on [26].

Conditions for the non-negativity of the variables of the economic and mathematical model: all are inalienable values, which also should not be equal to or less than zero. 
Table 5. The coefficient system used in the economic and mathematical model of bioethanol production.

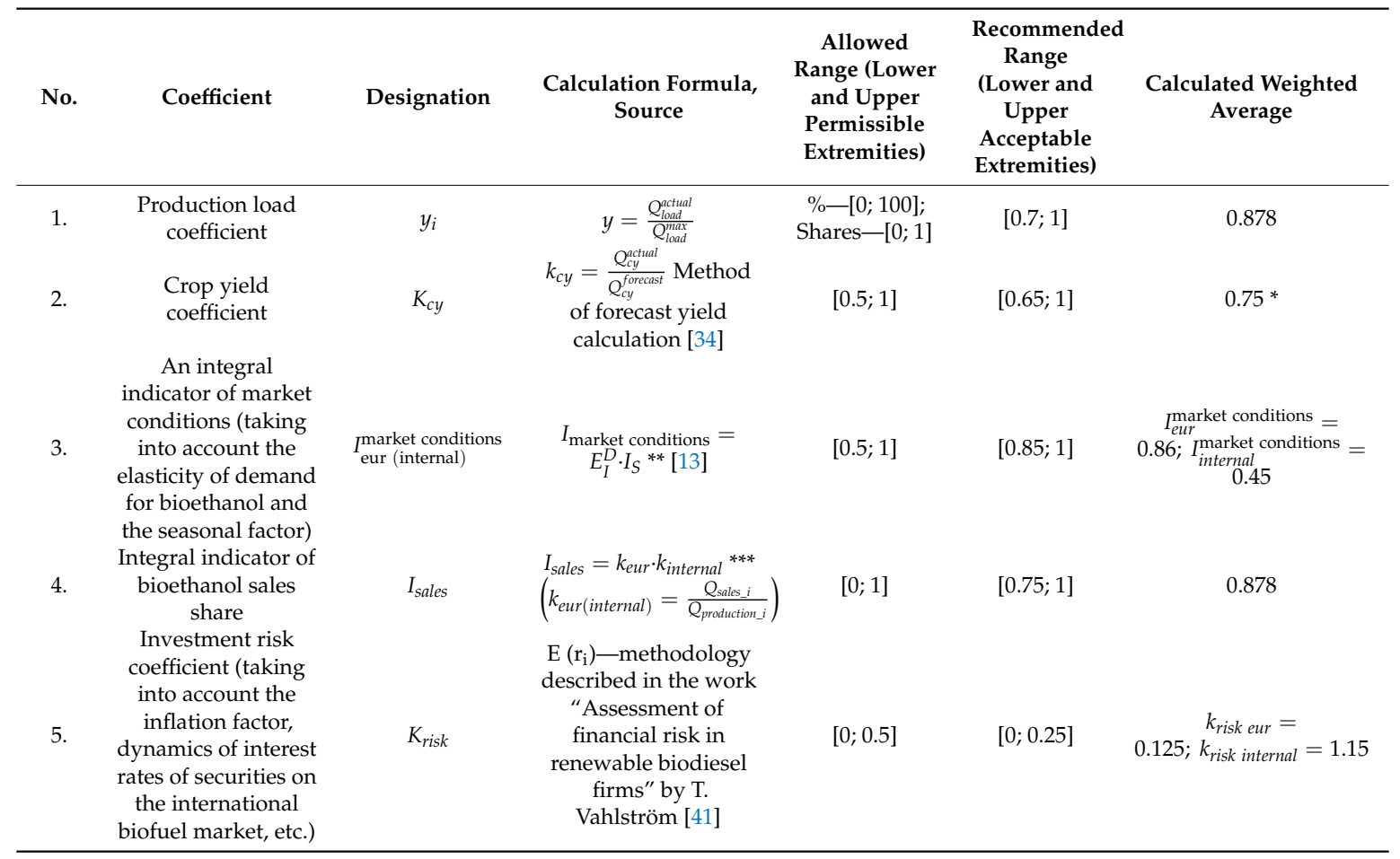

Source: calculated by authors based on the following methods $[5,18,19]$. Notes: ${ }^{*}$ calculated weighted average value of crop yield—sugar sorghum and corn (data from the Ministry of Agriculture of the PRC for 2018). ${ }^{* *} E_{I}^{D}$ —index of demand elasticity for bioethanol; $I_{S}$-index of seasonality in demand for bioethanol. This method is described in $[5,19]$. *** $k_{\text {eur }}$-indicator of bioethanol sales share in European markets (average); $k_{\text {internal }}$-indicator of bioethanol sales share in the internal market.

The generalized mathematical objective function is presented below. The function describes the profit, which has been received by alcohol enterprise (from producing bioethanol on organic raw materials). The function is a positive difference between the income (revenue) (which has been obtained from bioethanol sales) and bioethanol production costs:

$$
\text { max_P }=\left(\sum_{i=1}^{n} x_{i} \cdot P_{\text {sales }}\right) \cdot I_{\text {eur }}^{\text {market cond. }} \cdot I_{\text {internal }}^{\text {market cond. }} \cdot I_{\text {sales }} \cdot k_{\text {risk eur }} \cdot k_{\text {risk internal }}-\left(\sum_{i=1}^{n} x_{i} \cdot y_{i} \cdot P_{\text {purchase }}\right) \cdot k_{c y} \text {. }
$$

In order to calculate the proposed model, the authors of the current study have used the following:

Technical and economic data (cost, current and maximum production capacity, etc.) of Chinese alcohol enterprises-on the example of a number of alcohol enterprises from Table 2. On these alcohol enterprises it is proposed to set up bioethanol production;

Statistics on crop yields (which are proposed for use as raw materials in the bioethanol production) (data of National Bureau of Statistics of China and the Ministry of Agriculture of the PRC);

Data on price ranges and fluctuations on bioethanol of various origin, which is sold in European markets (information portals "The global statistics portal", "The globalpetrolprices.com", etc.).

Results have been obtained using the decision-making tool in the Microsoft Excel software.

The obtained calculations are given in Table 6. 
Table 6. Testing results of the economic and mathematical model of bioethanol production.

\begin{tabular}{|c|c|c|c|c|}
\hline No. & $\begin{array}{l}\text { Type of } \mathrm{i} \text {-th Raw } \\
\text { Resource }\end{array}$ & $\begin{array}{l}\text { Coefficient of Alcohol } \\
\text { Enterprises' Load, } \\
\text { Taking into Account } \\
\text { the Additional Load } \\
\text { of Bioethanol } \\
\text { Production, } y_{i}\end{array}$ & $\begin{array}{l}\text { Bioethanol } \\
\text { Production Volume in } \\
\text { Accordance with the } \\
\text { Load Coefficient, } x_{i} \text {, in } \\
\text { Thousands of Liters }\end{array}$ & $\begin{array}{l}\text { The Target Value of the } \\
\text { Function }(\max p \text { ) is the } \\
\text { Amount of Profit from the } \\
\text { Sale of Produced } \\
\text { Bioethanol, Taking into } \\
\text { Account } \mathrm{k}_{\text {eur (internal) }} \\
\text { mark.cond. and } \mathrm{k}_{\text {risk, }} \text { in } \\
\text { Thousands of USD }\end{array}$ \\
\hline 1. & Sugar sorghum & 0.97 & $97,571.029$ & 3220.29 \\
\hline \multirow[t]{2}{*}{2.} & Corn & 0.65 & $51,229.15$ & 2300.21 \\
\hline & In total & Average -0.81 & $148,800.179$ & 5520.5 \\
\hline
\end{tabular}

\section{Discussion}

There are constant discussions about biofuel production in the world. It is important to note that the participants in these discussions are actively developing bioenergy, financing research programs and stimulating the development of the biofuel market [22,27,41].

World biofuel production is growing at a rate that exceeds $10 \%$ per year. Most countries have adopted bioenergy programs. The particularly rapid development of bioenergy is observed in EU member states. European Union is planning to increase the share of biomass in the energy balance by $20 \%$ until $2020[37,38]$.

The bioenergy development in China, the CIS countries and the EU have been analyzed. The development of this innovation area is (among other things) due to the formation of technological platforms that:

- bring together the main stakeholders and ensure dialogue between society and business;

- attract investment in scientific and technological development;

- mobilize and direct available resources in the research and development sector, thereby promoting a more effective approach to innovation;

- stimulate coordination of European and national research programs;

- contribute to economic growth $[8,13,33,38]$.

The energy problem remains one of the global problems of humankind. There is a need to develop new and effective methods of energy production and replenishment of raw materials. This problem has become especially urgent in the last two decades due to a shortage of raw materials and energy on a global scale and increased requirements for the environmental safety of technologies [9,31].

In many ways, the problem of transferring biofuels from laboratories to everyday life is connected with the fact that in the production of biofuels one way or another, occupation of agricultural land is necessary, the definition of which is different in different legal systems. In addition, it is not always possible to determine exactly what role a particular locality plays in the region's agricultural ecosystem, which means that it is extremely difficult to determine the lands whose occupation by plants for biofuel production will cause minimal harm [38].

There is a conceptual approach, where "abandoned" or "deserted" lands (due to human migration) are allocated for the cultivation of such crops, however, cultivation, in this case, will demonstrate much lower productivity [31]. With low productivity of cultivation, the economic feasibility of biofuel production also decreases. Thus, in case of lower prices for traditional energy sources, it becomes more profitable to use oil products and extract energy from them. The latter is in terms of both the low cost of using the technology (there is a lot of experience and the corresponding infrastructure for such energy production) and relative predictability of the result, in contrast to the dependence on yield and weather conditions. At the same time, calculations of the growth in energy consumption show that in the case of the active introduction of biofuels in everyday life, the need for $1 \%$ of transport fuel 
requires $1 \%$ of agricultural land. Thereby, the actual need arises to use traditional methods of energy production [12,35].

There is a position that traditional and alternative energy should be connected in a single technological chain. A vivid example here is the experience of Belgium in creating the largest Bee Power Gent TPP. Electric capacity of 215 MW, and thermal capacity of 100 MW107 will give electricity to 450,000 European households without occupying new agricultural land, using, for example, wood chips [6]. It should be understood that it is impossible to create biofuels without a carbon footprint today, since, in the process of biomass preparation, traditional energy will be used anyway, directly and indirectly $[5,41]$.

Concerning the scientific discourse in the field of environmental problems, it is worth noting that it is possible to obtain mainly hydraulic and thermal energy among other energy resources. While the processes of obtaining hydraulic energy and its use can be considered relatively harmless to the environment, then this cannot be said about thermal energy. Most methods of thermal energy's extraction and conversion to other types, in particular to electric energy, inevitably lead to the discharge of pollutants into water sources and the release of heat into the atmosphere [3,14,39].

Researchers of environmental problems in the energy sector indicate that at least four basic principles must be taken into account in environmentally safe energy policy:

- $\quad$ the use of efficient and environmentally friendly energy resources;

- $\quad$ those technologies should be used for energy supply, which optimally uses the heat of fuel combustion and the heat of energy carriers;

- $\quad$ it is necessary to increase the use of non-traditional renewable energy resources $[8,42,43]$.

Today there are reports that alternative energy sources might pose an even greater danger to the ecology and climate of the Earth than traditional ones-oil, natural gas and even coal. Some researchers believe that despite all the advantages, biofuels have at least two significant disadvantages. Firstly, the combustion of biofuels contributes more to the greenhouse effect than standard fossil fuels, and secondly, the territories suitable for planting are limited. Nevertheless, biofuels have a number of advantages over petroleum fuels. Most studies have proven that they reduce emissions of harmful substances into the atmosphere, as well as greenhouse gases. It should be also noted that $\mathrm{CO}_{2}$ is absorbed by biomass from the atmosphere (during the period of biomass growth). Although some British scientists believe that there are 50\% more harmful emissions from the combustion of rapeseed biodiesel or corn bioethanol [3,5,19].

In general, the authors of the current study state the following problems that impede the use of ethanol as fuel:

- the high cost of bioethanol compared to gasoline;

- $\quad$ ethanol production from plant materials is not waste-free;

- low heating value and high ignition temperature of biofuels;

- $\quad$ the corrosive damage of ethanol to the fuel system;

- lignin waste in the processing of raw materials;

- formaldehyde emissions from alcohol products' combustion;

- disadvantages of the classical biological producer of alcohol-yeast:

- $\quad$ simultaneous respiration of yeast and anaerobic fermentation conditions;

- the inability of yeast to ferment starch and cellulose-containing substrates;

- $\quad$ high concentrations of alcohol and sugar are toxic for yeast $[18,19]$.

In general, the Chinese government has a positive attitude concerning green energy. Thus, in recent years, Chinese legal acts and strategies include the technology of mixing biofuels with petroleum fuels for transport. This technology will be in line with several Chinese government initiatives that are aimed at managing "urban problems" related to traffic, environmental pollution and public safety issues $[11,12,24]$. 
Ethanol fuel policies will support China's efforts to promote rural and agricultural development in the short and long term. In the short term, ethanol fuel supports President Xi's program and his structural reform program. With national grain stocks, China will reduce the fiscal burden and narrow the relative gap between high domestic prices and relatively lower world reference prices. In the long run, the adoption of a sustainable ethanol fuel program will increase farmers' incomes and improve rural economic development $[4,12,13,30]$.

\section{Conclusions}

Alternative energy sources, in particular biofuels, have gained the status of promising and competitive energy sources. In terms of public health and the environment, biofuels are part of China's long-term strategy to conserve resources, improve air quality and reduce China's dependence on imported fossil fuels. Scientific advances and new technologies for biofuel production allow solving the issues of biofuel industry establishment, increasing the country's energy security and improving the ecological state of most industrial cities.

There are the following positive results of applying the principles of bioenergetics. Namely, environmental friendliness, energy efficiency, the creation of additional added value for producers and the growing demand for bioenergy products (bioethanol and biodiesel) in the domestic and foreign markets.

In turn, the economic and mathematical model within the framework of alcohol enterprises' activities will allow analyzing the following:

- application of alternative bioethanol production technology based on crops-sugar sorghum and corn;

- the need for the production and sale of Chinese bioethanol in regional and world markets. Provided that Chinese bioethanol is competitive in terms of price (which is not higher than in other competing countries) and quality (ecological raw materials) criteria;

- changes in the specialization of a number of alcohol enterprises (partial reorientation to bioethanol production).

At the same time, it is necessary to take into account that the positive effect of the proposed model can be guaranteed only in the case of unchanged land use conditions. That is, only in the case of maintaining a balance between the lands intended for the livestock feed, the lands for agricultural products cultivation for human nutrition and lands for future biofuels cultivation. It should also be noted that the proposed model will retain its relevance only if the world level of "carbon debt" is maintained at the same level as in 2019. In addition, it is worth considering that the demand for the implementation of alternative energy models is dependent on oil prices and the situation on the global energy market. These conditions are a set of limitations for the study, affect its implementation value (the cost of adapting the model to the realities of the local market). Such conditions also put pressure on the possible reduction in the price of the presented technology due to the inability to quickly achieve economies of scale.

Further research should focus on solving the problems of expanding the volume of biomass available for processing into biofuels. Since today's agricultural activity occupies more than $70 \%$ of the free territory of the Earth, not occupied by glaciers, drainage basins and deserts, amid an increase in the world's population, food use of land can become more relevant for national economic systems. Thereby, the development of alternative energy in the context of biofuel can slow down due to the inability to attract more resources for processing.

Author Contributions: Z.Z. worked on the original idea. Z.Z. and M.L. performed the detailed conceptualization and investigation of this research. M.L. finalized the methodology and data analysis of this research. Z.Z. performed the write up of this project, including the writing of the original draft. M.L. performed data collection and data analysis. Z.Z. and M.L. wrote the final draft and conducted the review, proofreading, and editing for final submission. All authors have read and agreed to the published version of the manuscript. 
Funding: This research received no external funding.

Conflicts of Interest: The authors declare no conflict of interest.

\section{References}

1. Althaqeb, S. Survey of Energy Finance on the Corporate World. Int. J. Energy Econ. Policy 2017, 7, $153-158$.

2. BioFuels Digest. Available online: http://www.biofuelsdigest.com/bdigest/ (accessed on 22 September 2019).

3. Chachina, S.; Dvoyan, A. Obtaining bioethanol from organic raw materials. Omsk Sci. Bull. 2014, 2, $224-228$.

4. USDA. China: Biofuels Annual. Available online: https://www.fas.usda.gov/data/china-biofuels-annual-3 (accessed on 23 September 2019).

5. Hong, C.; Hsu, C. Economic growth, oil consumption and import intensity: Factor decomposition of imported crude oil model approach. Int. J. Energy Econ. Policy 2018, 8, 152-156.

6. CNN. Davos 2019: Live updates from the World Economic Forum. 2019. Available online: https: //edition.cnn.com/business/live-news/davos-2019-live-updates/index.html. (accessed on 6 February 2019).

7. Lazko, O. Scenarios for the Development of the Global Oil and Gas Industry until 2040. Available online: https://www2.deloitte.com/ru/ru/pages/about-deloitte/deloitte-in-press/stsenarii_razvitiya_ neftegazovoi_otrasli_2040.html (accessed on 9 May 2019).

8. Yuan, M.; Hong, M.; Zhang, M. Distributed solar PV in China: Growth and Challenges. Available online: https://www.wri.org/blog/2018/08/distributed-solar-pv-china-growth-and-challenges (accessed on 5 April 2019).

9. Nicita, A.; Seiermann, J. G20 Policies and Export Performance of Least Developed Countries by Alessandro Nicita and Julia Seiermann. Available online: https://unctad.org/en/pages/PublicationWebflyer.aspx? publicationid=1684 (accessed on 5 April 2019).

10. Siddiqi, M. Prospects for Development and Growth in the MENA Region in the Year ahead; Middle East Online: Londn, UK, 2015.

11. Xinhua News. U.S. Ethanol Industry Expects Normal China Trade to Boost Exports Growth. Available online: http://www.xinhuanet.com/english/2019-06/24/c_138168245.htm (accessed on 22 September 2019).

12. Tang, J. Chinese Fuel Ethanol Production 2018 Outlook. Available online: http://www.decision-innovation. com/blog/disinsights/chinese-fuel-ethanol-production-2018-outlook/ (accessed on 23 September 2019).

13. Kim, G.; Ward, M. China-Peoples Republic of Biofuels Annual. 2018. Available online: https://gain.fas.usda.gov/Recent\%20GAIN\%20Publications/Biofuels\%20Annual_Beijing_China\%20\%20Peoples\%20Republic\%20of_7-25-2018.pdf (accessed on 22 September 2019).

14. Barrows, S. Are Oil Industry Mergers Becoming Less Profitable? Int. J. Energy Econ. Policy 2018, 8, 31-38.

15. Bird, L.; Reger, A.; Heeter, J. Distributed Solar Incentive Programs: Recent Experience and Best Practices for Design and Implementation; National Renewable Energy Laboratory: Golden, CO, USA, 2012.

16. BNEF. Climatescope. Available online: http://global-climatescope.org/en/download/reports/countries/ climatescope-2014-np-en.pdf (accessed on 22 September 2019).

17. Bollen, J.; Rojas-Romagosa, H. Trade Wars: Economic Impacts of Us Tariff Increases and Retaliations, an International Perspective; Bonnet: Florence, Italy, 2018.

18. Vahlström, T. Assessment of Financial Risk in Renewable Biodiesel Firms. Available online: https://www. diva-portal.org/smash/get/diva2:785742/FULLTEXT01.pdf (accessed on 22 September 2019).

19. Romanenkov, V. The Study of the Effectiveness of Fertility Management in Agroecosystems Based on the Study of Yield Series in Long Field Experiments. 2015. Available online: http://downloads.igce.ru/journals/ PEMME/PEMME_2015/PEMME_2015_2/PEMME_2_2015_Romanenkov_V_Apdf (accessed on 22 September 2019).

20. Teixeira, M. Brazil Sets Sights on China's Ethanol Market, But High Volumes Unlikely. Available online: https://www.reuters.com/article/us-brazil-ethanol-china/brazil-sets-sights-on-chinas-ethanolmarket-but-high-volumes-unlikely-idUSKCN1VK0B6 (accessed on 22 September 2019).

21. US EPA. State Renewable Energy Resources. Available online: https://www.epa.gov/statelocalenergy/staterenewable-energy-resources (accessed on 5 April 2019).

22. Sapp, M. China Dialing Back Its E10 Ambitions on Lack of Feedstock: Biofuels Digest. 2019. Available online: https://www.biofuelsdigest.com/bdigest/2019/09/17/china-dialing-back-its-e10-ambitions-on-lackof-feedstock/ (accessed on 22 September 2019). 
23. Ren21. Global Status Report on Local Renewable Energy Policies. Available online: https://www.mofa.go.jp/ mofaj/gaiko/energy/irena/workshop1102/pdfs/pdf5.pdf (accessed on 5 April 2019).

24. Sustainable Energy Coalition. Current State of U.S. Renewable Energy Policy. Available online: http: //sustainableenergy.org/current-state-of-u-s-renewable-energy-policy/ (accessed on 5 April 2019).

25. IEA. Renewables Information 2019: Overview. Available online: https://webstore.iea.org/renewablesinformation-2019-overview (accessed on 23 September 2019).

26. Globalpetrolprices. Retail Energy Price Data. Available online: http://www.globalpetrolprices.com/ (accessed on 22 September 2019).

27. World Economic Forum. Shaping the Future of Energy. Available online: https://www.weforum.org/systeminitiatives/shaping-the-future-of-energy/articles (accessed on 5 April 2019).

28. The Statistics Portal. Global No.1 Business Data Platform. Available online: https://www.statista.com/ (accessed on 22 September 2019).

29. Enerdata. World Energy Consumption Statistics. Available online: https://yearbook.enerdata.net/totalenergy/world-consumption-statistics.html (accessed on 9 May 2019).

30. Ministry of Agriculture and Rural Affairs. Ministry of Agriculture and Rural Affairs of the People's Republic of China. Available online: http://english.agri.gov.cn/ (accessed on 22 September 2019).

31. Miller, N.; Christensen, A.; Eun Park, J.; Baral, A.; Malins, C.; Searle, S. Measuring and Addressing Investment Risk in the Second-Generation Biofuels Industry. 2013. Available online: https://www.theicct.org/sites/ default/files/publications/ICCT_AdvancedBiofuelsInvestmentRisk_Dec2013.pdf (accessed on 22 September 2019).

32. Eder, L. Forecasting Sustainable Development of Transport Sectors of Russia and EU: Energy Consumption and Efficiency. Int. J. Energy Econ. Policy 2018, 8, 74-80.

33. Energytrend. EnergyTrend-Solar Energy, Electric Vehicle, Power Battery, Wind Energy, Renewable Energy, Green Energy. Available online: https://m.energytrend.com/ (accessed on 5 April 2019).

34. Bloomberg. China Steps up Its Push into Clean Energy. Available online: https://www.bloomberg.com/news/ articles/2018-09-26/china-sets-out-new-clean-energy-goals-penalties-in-revised-plan (accessed on 5 April 2019).

35. BRINK. Renewable Energy: China has Set the Benchmark High, Asia. 2018. Available online: http: //www.brinknews.com/asia/renewable-energy-china-has-set-the-benchmark-high/ (accessed on 5 April 2019).

36. Burger, C.; Kuhlmann, A.; Richard, P.; Weinmann, J. Block Chain in the Energy Transition, German Energy Agency and European School of Management and Technology. Available online: http://www.esmt.org/ system/files_force/dena_esmt_studie_blockchain_english.pdf?download=1 (accessed on 5 April 2019).

37. OECD iLibrary. Ethanol Projections: Production and Use. Available online: https://www.oecd-ilibrary.org/ agriculture-and-food/oecd-fao-agricultural-outlook-2017-2026/ethanol-projections-production-and-use_ agr_outlook-2017-table174-en (accessed on 23 September 2019).

38. OECD. FAO Agricultural Outlook 2017-2026: BIOFUEL. Available online: https://stats.oecd.org/index.aspx? queryid=76849 (accessed on 23 September 2019).

39. Baraniuk, C. How China's Giant Solar Farms Are Transforming World Energy. 2016. Available online: http://www.bbc.com/future/story/20180822-why-china-is-transforming-the-worlds-solar-energy (accessed on 5 April 2019).

40. National Bureau of Statistics of China. Available online: http://www.stats.gov.cn/english/ (accessed on 22 September 2019).

41. World Economic Forum. The Key Trends That Will Shape Renewable Energy in 2018 and Beyond. Available online: https://www.weforum.org/agenda/2018/01/clean-energy-renewable-growth-sustainable-key-trends/ (accessed on 5 April 2019).

42. Mikita, M.; Kolcun, M.; Špes, M.; Vojtek, M.; Ivančák, M. Impact of electrical power load time management at sizing and cost of hybrid renewable power. Pol. J. Manag. Stud. 2017, 15, 154-162. [CrossRef]

43. DSIRE. Database of State Incentives for Renewables \& Efficiency. Available online: http://www.dsireusa.org/ (accessed on 5 April 2019).

(C) 2020 by the authors. Licensee MDPI, Basel, Switzerland. This article is an open access article distributed under the terms and conditions of the Creative Commons Attribution (CC BY) license (http://creativecommons.org/licenses/by/4.0/). 